\title{
Article \\ Chemoenzymatic Conversion of Biomass-Derived D-Xylose to Furfuryl Alcohol with Corn Stalk-Based Solid Acid Catalyst and Reductase Biocatalyst in a Deep Eutectic Solvent-Water System
}

\author{
Jianguang Liang ${ }^{\dagger}, \mathrm{Li} \mathrm{Ji}^{\dagger}$, Jiarui He, Shuxin Tang and Yucai He *(D) \\ National-Local Joint Engineering Research Center of Biomass Refining and High-Quality Utilization, \\ School of Pharmacy, Changzhou University, Changzhou 213164, China; liangjg@cczu.edu.cn (J.L.); \\ 19085235760@smaill.cczu.edu.cn (L.J.); 19439114@smail.cczu.edu.cn (J.H.); 17752417820@163.com (S.T.) \\ * Correspondence: yucaihe@cczu.edu.cn or heyucai2001@163.com \\ + These authors contributed equally to this work.
}

check for

updates

Citation: Liang, J.; Ji, L.; He, J.; Tang,

S.; He, Y. Chemoenzymatic

Conversion of Biomass-Derived

$D$-Xylose to Furfuryl Alcohol with

Corn Stalk-Based Solid Acid Catalyst

and Reductase Biocatalyst in a Deep

Eutectic Solvent-Water System

Processes 2022, 10, 113. https://

doi.org/10.3390/pr10010113

Academic Editor: Jun Xiang

Received: 28 November 2021

Accepted: 27 December 2021

Published: 6 January 2022

Publisher's Note: MDPI stays neutral with regard to jurisdictional claims in published maps and institutional affiliations.

Copyright: (C) 2022 by the authors. Licensee MDPI, Basel, Switzerland. This article is an open access article distributed under the terms and conditions of the Creative Commons Attribution (CC BY) license (https:// creativecommons.org/licenses/by/ $4.0 /)$.

\begin{abstract}
In this work, the feasibility of chemoenzymatically transforming biomass-derived $D$-xylose to furfuryl alcohol was demonstrated in a tandem reaction with $\mathrm{SO}_{4}{ }^{2-} / \mathrm{SnO}_{2}-\mathrm{CS}$ chemocatalyst and reductase biocatalyst in the deep eutectic solvent (DES)-water media. The high furfural yield $(44.6 \%)$ was obtained by catalyzing biomass-derived $D$-xylose $(75.0 \mathrm{~g} / \mathrm{L})$ in $20 \mathrm{~min}$ at $185^{\circ} \mathrm{C}$ with $\mathrm{SO}_{4}{ }^{2-} / \mathrm{SnO}_{2}-\mathrm{CS}(1.2 \mathrm{wt} \%)$ in DES ChCl:EG-water $(5: 95, v / v)$. Subsequently, recombinant $E$. coli CF cells harboring reductases transformed $D$-xylose-derived furfural $(200.0 \mathrm{mM})$ to furfuryl alcohol in the yield of $35.7 \%$ (based on $D$-xylose) at $35{ }^{\circ} \mathrm{C}$ and $\mathrm{pH} 7.5$ using HCOONa as cosubstrate in ChCl:EG-water. This chemoenzymatic cascade catalysis strategy could be employed for the sustainable production of value-added furan-based chemical from renewable bioresource.
\end{abstract}

Keywords: furfural; furfuryl alcohol; biological reduction; D-Xylose; E. coli CF

\section{Introduction}

With the rapid consumption of fossil-fuels, together with the growing global warming and environmental concerns, lignocellulosic biomass is regarded as ideal and promising alternative for producing biofuels and bio-based chemicals [1,2]. Biomass or biomassderived $D$-xylose has been industrially used for the production of furfural (FAL) with acid catalyst via dehydration reaction [1,3]. FAL is used in the production of furans, such as furfuralcohol (FOL), furoic acid (FA), etc. [4-6]. It has a wide range of applications in various industries, such as medicine, agriculture, chemicals, and cosmetics [7-9]. Recently, most catalytic production of FAL has used a variety of heterogeneous solid acid, such as sulfonated tin-based zeolite, sulfonated diamond powder (S-DP) and del-Nu-6(1) [4,5]. S-DP converted biomass-derived $D$-xylose to FAL with $76 \%$ yield at $200{ }^{\circ} \mathrm{C}$ in $5 \mathrm{~min}$. Catalyst del-Nu-6(1) catalyzed the conversion of biomass-derived $D$-xylose to FAL in $47 \%$ yield within $4 \mathrm{~h}$ at $170{ }^{\circ} \mathrm{C}$. Very recently, there has been great interest in utilizing biomassbased solid acid catalysts using biomass as carriers for the production of furfural due to the availability, abundance, and renewability of lignocellulosic materials. Catalyst CST, which was obtained from teff straw by simultaneous carbonization and sulfonation, could dehydrate $D$-xylose $(20 \mathrm{~g} / \mathrm{L})$ to FAL at $62 \%$ yield in $0.5 \mathrm{~h}$ at $170{ }^{\circ} \mathrm{C}$ [6]. Sulfonated tin-based argil catalyzed $D$-xylose into FAL in the yield of $57 \%$ at $180{ }^{\circ} \mathrm{C}$ in $20 \mathrm{~min}$ [7].

Due to the undesired side-reactions (e.g., FAL decomposition, self-coupling, or resinification) in pure water, several organic solvent-water biphasic media, such as toluene-water, $\gamma$-valerolactone (GVL)-water, and methyl isobutyl ketone (MIBK)-water, have been prepared as reaction systems for promoting the formation of FAL and enhancing the productivity of FAL by the extraction in situ of product FAL into the organic phase and separation of FAL from chemocatalysts [10]. In the past few years, unconventional and nonaqueous 
solvents such as ionic liquids (ILs) and deep eutectic solvents (DESs) have been designed and prepared to enhance the yields of FAL [11]. DESs can be synthesized by mixing hydrogen bond acceptors (HBAs) (e.g., choline chloride) and a hydrogen bond donors (HBDs) (e.g., amines, carboxylic acids, and polyols), which have gained a considerable interest due to their properties close to those of ILs [12]. As one kind of green and environmentally friendly solvent, DESs have been applied as pretreatment media for dissolving and pretreating lignocellulosic materials, and have been utilized to remove lignin, hydrolyze hemicelluloses, or synthesize FAL [13].

FAL is a versatile molecule for the synthesis of various furan-based chemicals [4,5]. As a value-added FAL derivative, furfuryl alcohol (FOL), which contains a furan substituted with a hydroxymethyl $\left(-\mathrm{CH}_{2} \mathrm{OH}\right)$ group, has been widely used for manufacturing synthetic fiber, rubber resin, furan resin, ascorbic acid, lubricant, lysine, vitamin $\mathrm{C}$, and hypergolic fuel in rocketry $[14,15]$. According to statistics, $60 \%$ of FAL is used to produce FOL. A series of catalysts (e.g., $\mathrm{Cu} / \mathrm{MgO}-\mathrm{Al}_{2} \mathrm{O}_{3}, \mathrm{Ni}-\mathrm{Cu} / \mathrm{SiO}_{2}, \mathrm{Pt} / \mathrm{m}-\mathrm{CN}-\mathrm{x}$ and, $\mathrm{Au} / \mathrm{Cu}-\mathrm{Al}_{2} \mathrm{O}_{3}$ ) [16-19] have been employed to prepare FOL from FAL via chemical approach. Although the chemical production of FOL can give high yields and good selectivities, high-energy consumption and environmental issues might limit its application. On the contrary, the biological method is attracting much attention due to its energy-saving and environmentally friendly performance [20-22]. FAL can be converted into FOL by some bacteria (e.g., B. coagulans NL01, B. cereus, and E. coli CF) $[7,20,22,23]$.

In this study, the production of FOL was conducted via chemical-enzymatic cascade conversion of biomass-derived $D$-xylose in a tandem reaction by sequential catalysis with biomass-based solid acid $\mathrm{SO}_{4}{ }^{2-} / \mathrm{SnO}_{2}-\mathrm{CS}$ chemocatalyst and E. coli $\mathrm{CF}$ whole-cells biocatalyst in DES ChCl:EG-water system. The effects of various chemical reaction parameters (e.g., $\mathrm{ChCl}$ :EG dosage, $\mathrm{SO}_{4}{ }^{2-} / \mathrm{SnO}_{2}-\mathrm{CS}$ dose, performance temperature, and catalytic time) on the production of FAL were investigated using biomass-derived $D$-xylose as feedstock. In addition, various biological reduction reaction parameters (e.g., $\mathrm{HCOONa}$ loading, performance $\mathrm{pH}$, bio-reduction temperature, metal ion additives, and substrate FAL loading, etc.) were tested on the biotransformation of FAL into FOL using whole-cells of recombinant $E$. coli $\mathrm{CF}$ harboring reductase. Finally, one-pot chemical-enzymatic synthesis of FOL from biomass-derived $D$-xylose was demonstrated by sequential dehydration with bio-compatible solid acid $\mathrm{SO}_{4}{ }^{2-} / \mathrm{SnO}_{2}-\mathrm{CS}$ and bio-reduction with recombinant $E$. coli CF cells.

\section{Materials and Methods}

\subsection{Materials and Reagents}

Corn stalks (CS) were collected from Lianyungang Farm (Changzhou Jiangsu province, P.R. China). Choline chcloride ( $\mathrm{ChCl}$ ), ethylene glycol (EG), D-xylose, glucose, $\mathrm{SnCl}_{4} \cdot 5 \mathrm{H}_{2} \mathrm{O}$, sodium formate $(\mathrm{HCOONa}), \mathrm{NADPH}$, sulfuric acid $\left(\mathrm{H}_{2} \mathrm{SO}_{4}\right)$, and other chemicals were purchased from Sino pharm Group Chemical Reagent Co., Ltd. (Shanghai, China).

\subsection{Chemical Conversion of D-Xylose to FAL in ChCl:EG-Water System}

The preparation of $\mathrm{SO}_{4}{ }^{2-} / \mathrm{SnO}_{2}-\mathrm{CS}$ solid acid catalyst: milled CS was soaked in $\mathrm{H}_{2} \mathrm{SO}_{4}$. The acid-treated CS (AT-CS) was mixed with $\mathrm{SnCl}_{4}-5 \mathrm{H}_{2} \mathrm{O}$ and anhydrous ethanol, then ammonia was slowly dripped into the mixture; the resulting colloidal solution was dried in an oven, the dried solid powder was dried after sulfonation in dilute $\mathrm{H}_{2} \mathrm{SO}_{4}$ and finally calcined in a muffle furnace to obtain $\mathrm{SO}_{4}{ }^{2-} / \mathrm{SnO}_{2}-\mathrm{CS}$ [24].

The conversion of $D$-xylose to $\mathrm{FAL}$ with $\mathrm{SO}_{4}{ }^{2-} / \mathrm{SnO}_{2}$-CS: in an autoclave reactor, $D$-xylose (3.0 g) and $\mathrm{SO}_{4}{ }^{2-} / \mathrm{SnO}_{2}-\mathrm{CS}(0-3.6 \mathrm{wt} \%)$ were mixed in $40 \mathrm{~mL}$ DES-water media (ChCl:EG, $0-40 \mathrm{v} \%$ ). This mixture was then blended by stirring ( $500 \mathrm{rpm}$ ) and heated to the desired performance temperature $\left(160-195^{\circ} \mathrm{C}\right)$ for reaction time (10-50 min). After the catalytic reaction was complete, the reactor was allowed to cool down to room temperature in an ice-water cooling bath immediately. 


\subsection{Bio-Reduction in FAL to FOL with CF Whole-Cells}

To enhance the bio-reduction efficiency of $\mathrm{CF}$ whole-cells, several biological reaction factors were investigated on the biotransformation of $D$-xylose-derived FAL. To investigate the effect of ChCl:EG loading on the bio-reduction activity, CF wet cells $(0.050 \mathrm{~g} / \mathrm{mL})$ were incubated $40 \mathrm{~mL}$ DES-water (DES ChCl:EG dosage 0-40 v\%) were blended with $D$-xylosederived FAL (200.0 mM), HCOONa (3.0 mol HCOONa/mol FAL), and NADPH (1.0 $\mu \mathrm{mol}$ $\mathrm{NADPH} / \mathrm{mol} \mathrm{FAL}$ ) at $35^{\circ} \mathrm{C}$. To evaluate the effect of the amount of cosubstrate $\mathrm{HCOONa}$ on bio-reduction activity, different amounts of $\mathrm{HCOONa}(\mathrm{HCOONa} / \mathrm{FAL}=0-5 / 1 \mathrm{~mol} / \mathrm{mol})$ were loaded to $40 \mathrm{~mL}$ DES-water (ChCl:EG $5 \mathrm{v} \%$, pH 7.5) with $D$-xylose-derived FAL $(200.0 \mathrm{mM}), \mathrm{CF}$ wet cells $(0.050 \mathrm{~g} / \mathrm{mL})$, and NADPH $(1.0 \mu \mathrm{mol} \mathrm{NADPH} / \mathrm{mol} \mathrm{FAL})$ at $35^{\circ} \mathrm{C}$. To test the effect of temperature and $\mathrm{pH}$ on the biocatalytic activity, $D$-xylose-derived FAL $(200.0 \mathrm{mM})$ and CF wet cells $(0.050 \mathrm{~g} / \mathrm{mL})$ were incubated in $40 \mathrm{~mL}$ DES-water (ChCl: EG $5 \mathrm{v} \%, \mathrm{pH}$ pH 5.0-9.5) containing HCOONa (3.0 mol HCOONa/mol FAL) and NADPH $(1.0 \mu \mathrm{mol} \mathrm{NADPH} / \mathrm{mol} \mathrm{FAL})$ at $25-50{ }^{\circ} \mathrm{C}$. To evaluate the effect of metal ion additives on bio-reduction activity, several metal ions $\left(\mathrm{Sn}^{4+}, \mathrm{Zn}^{2+}, \mathrm{Co}^{2+}, \mathrm{Fe}^{3+}, \mathrm{Mn}^{2+}, \mathrm{Fe}^{2+}, \mathrm{Al}^{3+}, \mathrm{Ca}^{2+}\right.$, $\mathrm{Cu}^{2+}, \mathrm{Mg}^{2+}$, and $\left.\mathrm{Li}^{+}\right)(0.50 \mathrm{mM})$ were separately added to $40 \mathrm{~mL}$ DES-water (ChCl:EG $5 \mathrm{v} \%$, pH 6.5) with $D$-xylose-derived FAL (200.0 mM), CF wet cells $(0.050 \mathrm{~g} / \mathrm{mL}), \mathrm{HCOONa}$ (3.0 mol HCOONa/mol FAL), and NADPH $(1.0 \mu \mathrm{mol} \mathrm{NADPH} / \mathrm{mol} \mathrm{FAL})$ at $35^{\circ} \mathrm{C}$. To evaluate the effect of $\mathrm{Sn}^{4+}$ on the bio-reduction activity, different doses of $\mathrm{Sn}^{4+}(0-5.0 \mathrm{mM})$ were added to $40 \mathrm{~mL}$ DES-water media (pH 7.5) with $D$-xylose-derived FAL (200.0 mM), CF wet cells $(0.050 \mathrm{~g} / \mathrm{mL}), \mathrm{HCOONa}(3.0 \mathrm{~mol} \mathrm{HCOONa} / \mathrm{mol} \mathrm{FAL})$, and NADPH $(1.0 \mu \mathrm{mol}$ $\mathrm{NADPH} / \mathrm{mol} \mathrm{FAL}$ ) at $35^{\circ} \mathrm{C}$. The contents of FAL and FOL were determined by HPLC.

\subsection{Analytical Methods}

The yield of FAL from $D$-xylose was calculated by the following formula:

$$
\text { FAL yield }(\%)=\frac{\text { FAL produced }(\mathrm{mM})}{D-\text { Xylose }(\mathrm{mM})} \times 100 \%
$$

The FOL yield was obtained using the below equation:

$$
\text { FOL yield }(\%)=\frac{\text { FOL produced }(\mathrm{mM})}{\text { Initial FAL }(\mathrm{mM})} \times 100 \%
$$

Furan-based compounds (e.g., FAL and FOL) were measured with HPLC (LC-2030C 3D SHIMADZU, Kyoto, Japan) equipped with reverse-phase C18 (Discovery C18, $3.9 \mathrm{~mm} \times 150 \mathrm{~mm}$, $4 \mu \mathrm{m})$ (Bellefonte, PA, USA), which were eluted by $0.4 \%\left(\mathrm{NH}_{4}\right)_{2} \mathrm{SO}_{4} / \mathrm{CH}_{3} \mathrm{OH}(95: 5, v / v)$ at a flow rate of $0.6 \mathrm{~mL} / \mathrm{min}$. FAL and FOL were assayed at 254 and $210 \mathrm{~nm}$, respectively.

\section{Results and Discussion}

\subsection{Optimization of Conditions for FAL Production}

DESs have been utilized in the sustainable chemical processes due to their unique properties [25], which have been regarded as a green cosolvent to promote the generation of FAL in the aqueous system [22]. It is very likely that the established DES-water media can facilitate the formation of FAL molecules and prevent the undesired degradation or cross polymerization of FAL [24]. In this study, DES (ChCl:EG) was used as additive for the establishment of $\mathrm{ChCl}$ :EG-water media for catalyzing $D$-xylose into FAL. The volumetric ratio of ChCl:EG to water phase had a profound effect on the dehydration of $D$-xylose. Different loading of $\mathrm{ChCl}$ :EG were separately mixed with water to form various ChCl:EGwater media. In $40 \mathrm{~mL}$ aqueous media, the $\mathrm{ChCl}$ :EG dosage was varied as $0-40 \mathrm{v} \%$. The synthesis of FAL was carried out by using $\mathrm{SO}_{4}{ }^{2-} / \mathrm{SnO}_{2}-\mathrm{CS}$ as catalyst at $185^{\circ} \mathrm{C}$ for $20 \mathrm{~min}$. As illustrated in Figure 1a, as the ChCl:EG loading increased from 0 to $5 \mathrm{v} \%$, the FAL yield were gradually raised. When the ChCl:EG dose reached $5 \mathrm{v} \%$, the yield of FAL was $44.6 \%$. By increasing ChCl:EG content from 5 to $40 \mathrm{v} \%$, the FAL yields decreased considerably. Thus, the optimum ChCl:EG loading was $5 \mathrm{v}$. When the DES ChCl:EG loading increased 
in $\mathrm{ChCl}: \mathrm{EG}$-water, it was very likely that the rehydration and degradation reaction of FAL would be weakened. However, an excessive addition of $\mathrm{ChCl}$ :EG might reduce the contact opportunity of substrate $D$-xylose to catalyst $\mathrm{SO}_{4}{ }^{2-} / \mathrm{SnO}_{2}-\mathrm{CS}$, which would result in the decreased FAL yields.
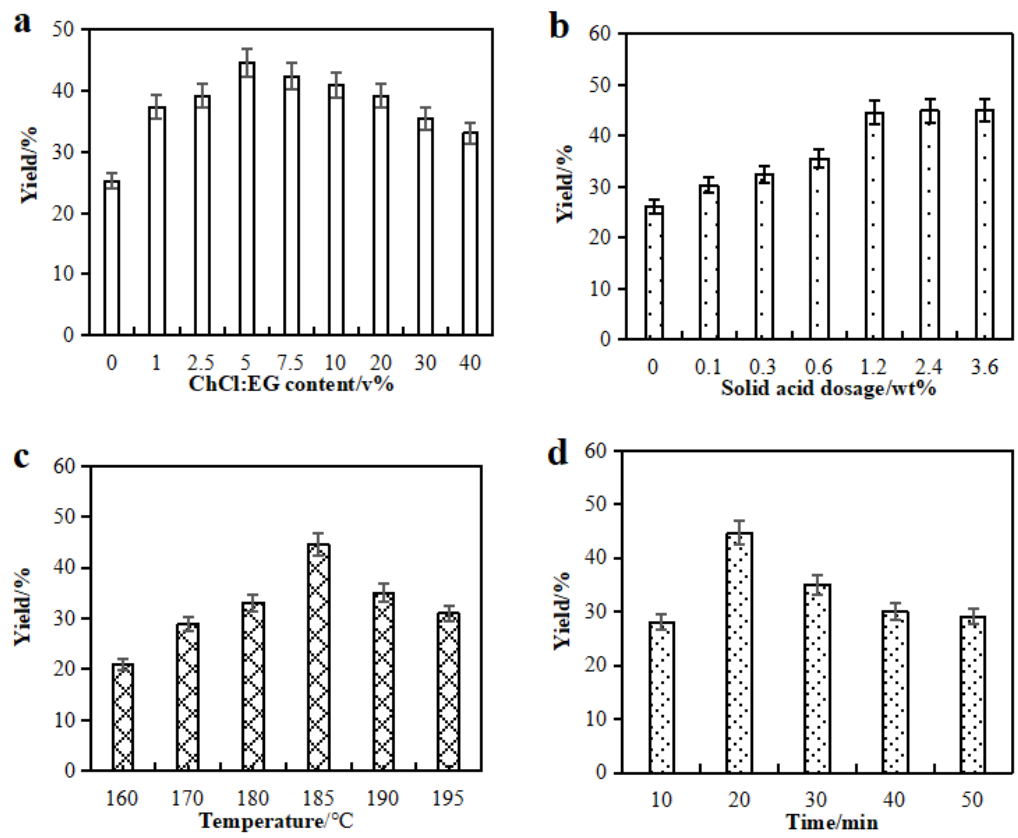

Figure 1. Effects of DES ChCl:EG (0-40 v\%) on the FAL production via D-xylose dehydration (a); Effects of solid acid dose (0-3.6 $\mathrm{wt} \%$ ) on the FAL production via D-xylose dehydration in ChCl:EGwater $(5: 95, v / v)(\mathbf{b})$; Effects of dehydration temperature $\left(160-195{ }^{\circ} \mathrm{C}\right)$ on the FAL production via D-xylose dehydration in $20 \mathrm{~min}$ in ChCl:EG-water $(5: 95, v / v)$ (c); Effects of dehydration time (10-50 $\mathrm{min})$ on the FAL production via D-xylose dehydration at $185{ }^{\circ} \mathrm{C}$ in $\mathrm{ChCl}$ :EG-water $(5: 95, v / v)(\mathbf{d})$.

To further promote the FAL yields, it is necessary to obtain the optimum reaction conditions [26,27]. In ChCl:EG-water $(5: 95, v / v), \mathrm{SO}_{4}{ }^{2-} / \mathrm{SnO}_{2}-\mathrm{CS}$ loading $(0-3.6 \mathrm{wt} \%)$, performance temperature $\left(160-195^{\circ} \mathrm{C}\right)$, and reaction time $(10-50 \mathrm{~min})$ were optimized using $D$-xylose as feedstock. Upon raising $\mathrm{SO}_{4}{ }^{2-} / \mathrm{SnO}_{2}-\mathrm{CS}$ dose from 0 to $1.2 \mathrm{wt} \%$, the FAL yields gradually increased (Figure $1 \mathrm{~b}$ ). The highest yield of FAL reached $44.6 \%$. When the $\mathrm{SO}_{4}{ }^{2-} / \mathrm{SnO}_{2}-\mathrm{CS}$ loading was raised from $1.2 \mathrm{wt} \%$ to $3.6 \mathrm{wt} \%$, FAL yields had no significant change. Thus, the optimum dose of $\mathrm{SO}_{4}{ }^{2-} / \mathrm{SnO}_{2}-\mathrm{CS}$ was $1.2 \mathrm{wt} \%$. When $D$-xylose dehydration reactions were culminated at diverse dehydration reaction time $(10,20,30,40$ and $50 \mathrm{~min})$ and diverse reaction temperature $(160,170,180,185,190$, and $195^{\circ} \mathrm{C}$ ), the highest FAL yield was obtained at $185^{\circ} \mathrm{C}$ in $20 \mathrm{~min}$ (Figure $1 \mathrm{~d}$ ). Moreover, the conversion rate of xylose to FAL was $96.0 \%$. Higher temperatures $\left(190-195{ }^{\circ} \mathrm{C}\right)$ resulted in a lower yield of FAL, probably because higher temperatures accelerated the occurrence of undesired side-reactions. Clearly, $\mathrm{SO}_{4}{ }^{2-} / \mathrm{SnO}_{2}-\mathrm{CS}$ catalyzed dehydration of $D$-xylose into FAL $(223.0 \mathrm{mM})$ in the highest yield of $44.6 \%$ in ChCl:EG-water $(5: 95, v / v)$.

\subsection{Optimization for Bio-Reduction in FAL to FOL}

The bio-reduction in carbonyl compounds into alcohols has attracted considerable interest due to the product specificity, mild reaction, and high efficiency [7,28-30]. To effectively transform FAL to FOL with CF cells in ChCl:EG-water, various parameters (e.g., cosubstrate $\mathrm{HCOONa}$, bio-reduction $\mathrm{pH}$, bio-reduction temperature, metal ion additives, cell dosage, etc.). 
Upon raising the HCOONa concentration from 0 to $3 \mathrm{~mol} \mathrm{HCOONa/mol} \mathrm{FAL,} \mathrm{the}$ catalytic activity gradually increased (Figure 2a). By increasing HCOONa loading from 3 to $5 \mathrm{~mol} \mathrm{HCOONa} / \mathrm{mol} \mathrm{FAL}$, the biocatalytic activity gradually decreased. It is likely that the viscosity of reaction media increased so that the FAL reducing activity decreased. Thus, the appropriate molar ratio of cosubstrate HCOONa to FAL was 3:1. Biocatalytic temperature had a profound influence on the FOL formation. The biocatalytic activity increased with the increase in reaction temperature from 25 to $35^{\circ} \mathrm{C}$. High bio-redcution activity was observed at $35{ }^{\circ} \mathrm{C}$ (Figure $2 \mathrm{~b}$ ). When the performance temperature exceeded $35^{\circ} \mathrm{C}$, the reductase activity dropped considerably, possibly due to the thermal deactivation of reductase in whole-cells during the bio-reduction [2,7]. Significantly, the optimal reaction temperature was $35^{\circ} \mathrm{C}$. By increasing the reaction $\mathrm{pH}$ from 5.0 to 7.5 at $35^{\circ} \mathrm{C}$, the biocatalytic activity reached the highest value (Figure $2 \mathrm{c}$ ). Over $\mathrm{pH} 7.5$, the biocatalytic activity decreased clearly. Thus, the optimum reaction $\mathrm{pH}$ was 7.5 .
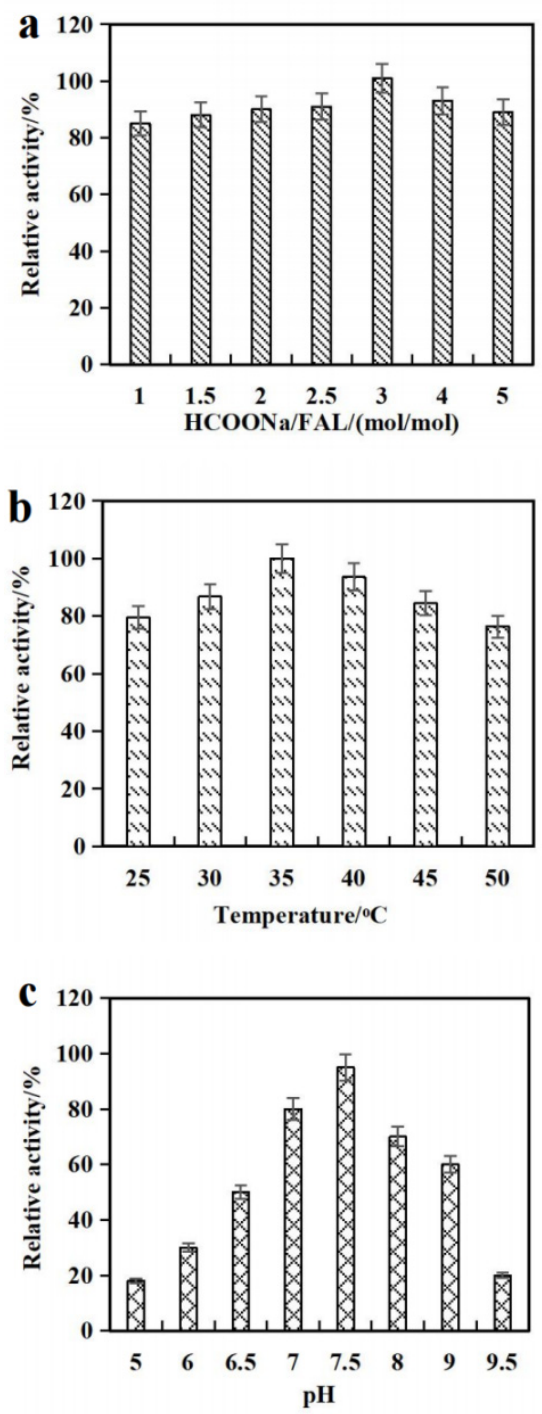

Figure 2. The effect of HCOONa-to-FAL molar ratio on the FAL-reducing activity (a); The effect of bioreaction temperature on the FAL-reducing activity (b); The effect of bioreaction $\mathrm{pH}$ on the FAL-reducing activity (c).

The effects of various metal ions $(0.50 \mathrm{mM})$ on the reductase activity were also examined in the $\mathrm{ChCl}: \mathrm{EG}-$ water at $35^{\circ} \mathrm{C}$ and $\mathrm{pH}$ 7.5. Metal ions types and dosages could significantly influence the activities of alcohol dehydrogenases [31]. In this study, $\mathrm{SnCl}_{4}$, $\mathrm{ZnCl}_{2}, \mathrm{CoCl}_{2}, \mathrm{FeCl}_{3}, \mathrm{MnCl}_{2}, \mathrm{FeCl}_{2}, \mathrm{AlCl}_{3}, \mathrm{CaCl}_{2}, \mathrm{CuCl}_{2}, \mathrm{MgCl}_{2}$, and $\mathrm{LiCl}$ (0.50 mM) were 
separately added into bio-reduction system. Clearly, $\mathrm{Mg}^{2+}$ and $\mathrm{Li}^{+}$inhibited the reductase activity. While $\mathrm{Sn}^{4+}, \mathrm{Zn}^{2+} \mathrm{Co}^{2+}$, and $\mathrm{Fe}^{3+}$ could significantly promote the reductase activity (Figure 3a). $\mathrm{Sn}^{4+}$ could give the highest reductase activity. During the utilization of $\mathrm{SO}_{4}{ }^{2-} / \mathrm{SnO}_{2}-\mathrm{CS}$, element $\mathrm{Sn}$ might be dissolved in the reaction system. The effects of different loading of $\mathrm{Sn}^{4+}(0-5.0 \mathrm{mM})$ on the bio-reduction activity were also tested. It was observed that $0.1-0.8 \mathrm{mM} \mathrm{Sn}^{4+}$ could be promote reductase activity. Clearly, the optimal $\mathrm{Sn}^{4+}$ dose was $0.50 \mathrm{mM}$, and the reductase activity of CF cells was increased by 1.2 -fold compared to the control in the absence of $\mathrm{Sn}^{4+}$ (Figure 3b). By increasing $\mathrm{Sn}^{4+}$ dosage from 0.9 to $5.0 \mathrm{mM}$, the activity gradually dropped from $2.1 \%$ to $17.9 \%$. These results indicated that $\mathrm{Sn}^{4+}$ and $\mathrm{SO}_{4}{ }^{2-} / \mathrm{SnO}_{2}$-CS were compatible towards reductase in CF whole-cells to some extent. From the view of biochemical aspect, this property would facilitate the chemoenzymatic conversion of biomass-derived $D$-xylose into FOL without removal $\mathrm{Sn}^{4+}$ and $\mathrm{SO}_{4}{ }^{2-} / \mathrm{SnO}_{2}$-CS. To further enhance the FAL-reducing activity, the combination of $\mathrm{Sn}^{4+}$ and other metal ion $\left(\mathrm{Zn}^{2+}, \mathrm{Co}^{2+}, \mathrm{Fe}^{3+}, \mathrm{Fe}^{2+}\right.$ or $\left.\mathrm{Mn}^{2+}\right)$ on conversion of FAL with $E$. coli $\mathrm{CF}$ is under progress.
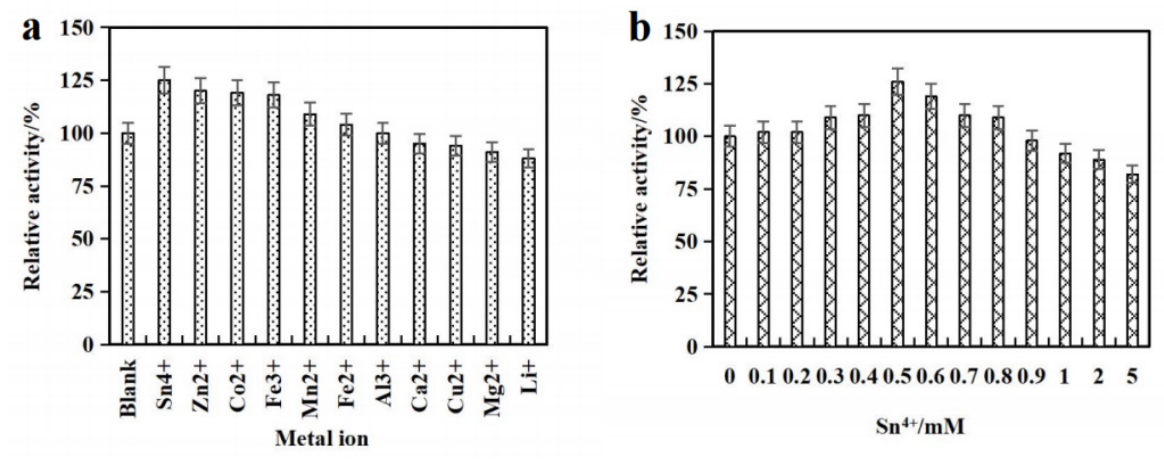

Figure 3. The effect of metal ion additives on the FAL-reducing activity (a); The influence of $\mathrm{Sn}^{4+}$ dosage on the FAL-reducing activity $(\mathbf{b})$.

Furthermore, the CF cell dosage might have significant influence on the FOL yield. As illustrated in Figure 4, the FOL formation clearly increased with increased cell dosage from 0.025 to 0.050 (wet weight) $/ \mathrm{mL}$. At $0.050 \mathrm{~g} / \mathrm{mL}, 150 \mathrm{mM}$ FAL could be completely catalyzed into FOL. By increasing CF cell dosage from 0.050 to $0.075 \mathrm{~g} / \mathrm{mL}$, no significant change was observed on the FOL yield. Over $0.075 \mathrm{~g} / \mathrm{mL}$, the FOL yield dropped gradually. It is likely that the high-loading of cells might cause the increase in the reaction system's viscosity, and the FOL yield significantly decreased.

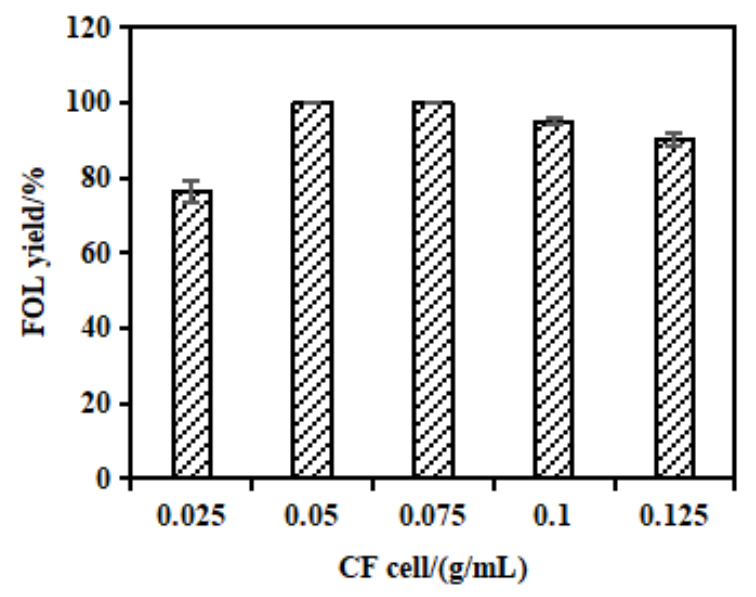

Figure 4. The effect of $\mathrm{CF}$ cell dosage on the FOL yield $\left(150 \mathrm{mM} \mathrm{FAL}, 35^{\circ} \mathrm{C}, \mathrm{pH} 7.5,0.50 \mathrm{mM} \mathrm{Sn}{ }^{4+}, 8 \mathrm{~h}\right)$. 


\subsection{Chemical-Enzymatic Conversion of D-Xylose into FOL}

In the past few years, chemical-enzymatic cascade catalysis has been applied to synthesize highly value-added chemicals [32]. In the DES-water system, catalysis of $D$-xylose to FAL with $\mathrm{SO}_{4}{ }^{2-} / \mathrm{SnO}_{2}-\mathrm{CS}$ and bio-reduction in FAL to FOL with recombinant E. coli $\mathrm{CF}$ were combined into the transformation of $D$-xylose to $\mathrm{FOL}$ in a cascade reaction manner. In an autoclave reactor containing $40 \mathrm{~mL} \mathrm{ChCl:EG-water}(5: 95, v / v)$ at $185^{\circ} \mathrm{C}$, $3.0 \mathrm{~g} \mathrm{D}$-xylose could give $223.0 \mathrm{mM}$ FAL in $20 \mathrm{~min}$. Then, after adjusting $\mathrm{pH}$ value to 7.5, the FAL liquor A obtained was diluted with KPB (100 mM, pH 7.5) to form FAL liquor B (50-200 mM FAL). E. coli CF whole cells $(0.050 \mathrm{~g} / \mathrm{mL}), \mathrm{Sn}^{4+}(0.50 \mathrm{mM}), \mathrm{HCOONa}$ $(3.0 \mathrm{~mol} \mathrm{HCOONa} / \mathrm{mol} \mathrm{FAL})$, and NADPH $(1.0 \mu \mathrm{mol} \mathrm{NADPH} / \mathrm{mmol} \mathrm{FAL})$ were added to initiate the bioconversion of FAL liquor $\mathrm{B}$ at $35^{\circ} \mathrm{C}$. Time courses for the bioconversion of dilute $D$-xylose-derived FAL (50-200 $\mathrm{mM}$ ) were monitored (Figure 5). It was found that 50-100 mM FAL could be completely converted into FOL at $35^{\circ} \mathrm{C}$ within $6 \mathrm{~h}$, while $150 \mathrm{mM}$ FAL could be fully catalyzed to FOL within $8 \mathrm{~h}$. At $200 \mathrm{mM}$, FOL was obtained in the yield of $80.0 \%$. Conversion of $D$-xylose to FOL in $35.7 \%-44.6 \%$ yield (based on $D$-xylose) was conducted via sequential catalysis with $\mathrm{SO}_{4}{ }^{2-} / \mathrm{SnO}_{2}-\mathrm{CS}$ and CF cells in ChCl:EG-water system. Compared with previous reports [14,33], this strategy could be used to utilize FAL for FOL production within a relatively short reaction time. In this study, an effective chemical-enzymatic strategy for transforming $D$-xylose to $F O L$ via sequential $\mathrm{SO}_{4}{ }^{2-} / \mathrm{SnO}_{2}-\mathrm{CS}$ catalysis and $\mathrm{CF}$ whole-cell bio-reduction was successfully demonstrated.

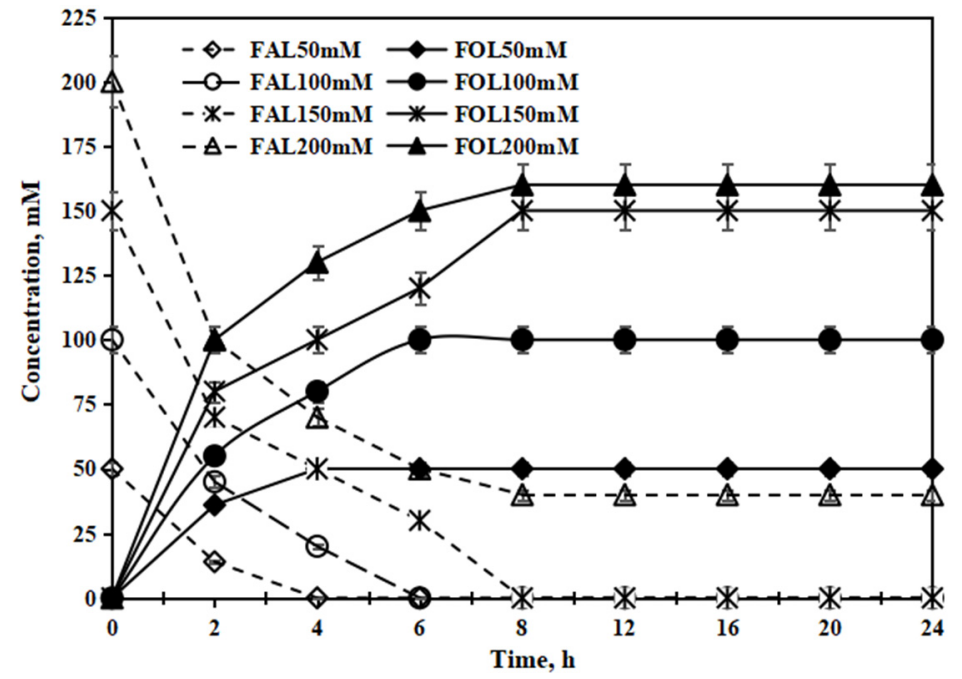

Figure 5. Time courses for the bio-reduction in D-xylose-derived FAL (50-200 $\mathrm{mM}$ ) by whole cells in the presence of HCOONa (3.0 mol HCOONa/mol FAL).

This study provided a tandem catalytic process for chemoenzymatically valorizing $D$-xylose to FOL in one same autoclave reactor (Figure 6). This process might cut down the equipment input and reduce the usage of solvents (e.g., water and DES). The concentration of FAL in this tandem catalytic process was not very high, by using $D$-xylose as feedstock. The FAL yield need to be drastically enhanced for the efficient production of FOL. Besides the effectiveness of catalysts for high yield and high selectivity in the formation of products, solvents also play an important role in enhancing products yield [34,35]. DESs are inexpensive, easy to prepare, lower toxicity and environmentally friendly solvents, which have been utilized to conduct chemocatalysis and biocatalysis reactions [36-39]. This combined chemical-enzymatic strategy for tandemly transforming $D$-xylose to FOL by $\mathrm{SO}_{4}{ }^{2-} / \mathrm{SnO}_{2}-\mathrm{CS}$ and E. coli CF whole-cells in DES ChCl:EG-water. HCOONa was chosen as the cosubstrate for the bio-reduction in FAL into FOL. Compared with glucose as cosubstrate $[27,31]$, this developed process using HCOONa as cosubstrate was regarded as greener approach in the industrial applications [40]. From the view of industrial biotechnology applications, it was of great interest to develop a cost-effective process 
for the enhancement of FAL production [27,41], and to further promote FOL formation with high reductase activity. This established one-pot chemoenzymatic strategy might facilitate the conversion of biomass resource into value-added furan-based chemicals in an environmentally friendly reaction media.

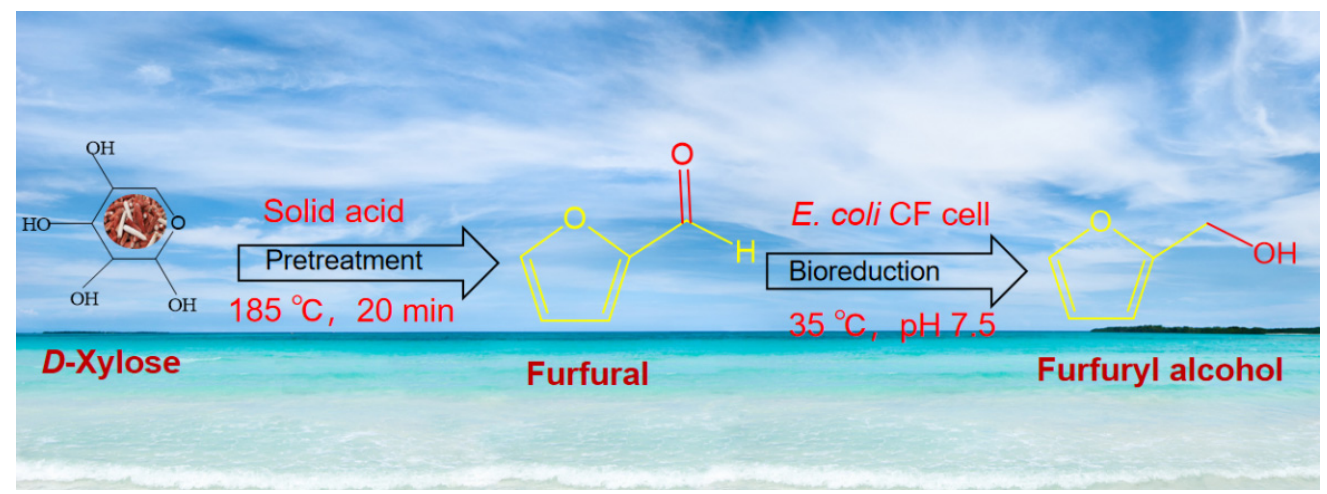

Figure 6. Tandem catalysis for chemoenzymatically valorizing $D$-xylose to FOL.

\section{Conclusions}

In the $D$-xylose dehydration, high FAL yield $(44.6 \%)$ was achieved by catalyzing $D$-xylose $(75.0 \mathrm{~g} / \mathrm{L})$ with $\mathrm{SO}_{4}{ }^{2-} / \mathrm{SnO}_{2}$-CS $(1.2 \mathrm{wt} \%)$ in DES ChCl:EG-water $(5: 95, v / v)$ at $185^{\circ} \mathrm{C}$ within $20 \mathrm{~min}$. Subsequently, E. coli $\mathrm{CF}$ whole cells could convert $D$-xylose-derived FAL (50-200 mM) into FOL in the yield of $80-100 \%$ (based on FAL) within $8 \mathrm{~h}$ at $35^{\circ} \mathrm{C}$ and $\mathrm{pH} 7.5$ using HCOONa as cosubstrate. The one-pot conversion of $D$-xylose to FOL at $35.7 \%-44.6 \%$ yield (based on $D$-xylose) was conducted via sequential catalysis with $\mathrm{SO}_{4}{ }^{2-} / \mathrm{SnO}_{2}-\mathrm{CS}$ and $\mathrm{CF}$ cells in $\mathrm{ChCl}$ :EG-water. This combined catalytic strategy provides an environmentally friendly idea for the conversion of biomass-derived $D$-xylose to FOL.

Author Contributions: Conceptualization, Methodology and Writing original draft, J.L. and L.J.; Data curation, J.H.; Software, S.T.; Supervision, Review and revising manuscript, Y.H. All authors have read and greed to the published version of the manuscript.

Funding: The authors gratefully acknowledge the Postgraduate Research \& Practical Innovation Program of Jiangsu Province (KYCX21-2867; SJCX21-1244; SJCX21-1245; SJCX21-1246).

Institutional Review Board Statement: Not applicable.

Informed Consent Statement: Not applicable.

Data Availability Statement: Not applicable.

Conflicts of Interest: The authors declare no conflict of interest.

\section{References}

1. Li, Q.; Di, J.; Liao, X.; Ni, J.; Li, Q.; He, Y.C.; Ma, C. Exploration of benign deep eutectic solvent-water systems for the highly efficient production of furfurylamine from sugarcane bagasse via chemoenzymatic cascade catalysis. Green Chem. 2021, 23, 8154-8168. [CrossRef]

2. He, Y.C.; Jiang, C.X.; Chong, G.G.; Di, J.H.; Wu, Y.F.; Wang, B.Q.; Xue, X.X.; Ma, C.L. Chemical-enzymatic conversion of corncobderived Xylose to furfuralcohol by the tandem catalysis with $\mathrm{SO}_{4}{ }^{2-} / \mathrm{SnO}_{2}$-kaoline and E. coli CCZU-T15 cells in toluene-water media. Bioresour. Technol. 2017, 245, 841-849. [CrossRef]

3. Ni, J.; Li, Q.; Gong, L.; Liao, X.; Zhang, Z.; Ma, C.; He, Y. Highly efficient chemoenzymatic cascade catalysis of biomass into furfurylamine by a heterogeneous shrimp shell-based chemocatalyst and an $\omega$-transaminase biocatalyst in deep eutectic solvent-water. ACS Sustain. Chem. Eng. 2021, 9, 13084-13095. [CrossRef]

4. Delbecq, F.; Takahashi, Y.K.; Kondo, T.; Corbas, C.C.; Ramos, E.R.; Len, C. Microwave assisted efficient furfural production using nano-sized surface-sulfonated diamond powder. Catal. Commun. 2018, 110, 74-78. [CrossRef]

5. Lima, S.; Pillinger, M.; Valente, A.A. Dehydration of d-xylose into furfural catalysed by solid acids derived from the layered zeolite Nu-6(1). Catal. Commun. 2008, 9, 2144-2148. [CrossRef]

6. Dulie, N.W.; Woldeyes, B.; Demsash, H.D. Synthesis of lignin-carbohydrate complex-based catalyst from Eragrostistef straw and its catalytic performance in xylose dehydration to furfural. Int. J. Biol. Macromol. 2021, 171, 10-16. [CrossRef] 
7. Xue, X.X.; Ma, C.L.; Di, J.H.; Huo, X.Y.; He, Y.C. One-pot chemo-enzymatic conversion of D-xylose to furfuralcohol by sequential dehydration with oxalic acid plus Tin-based solid acid and bioreduction with whole-cells. Bioresour. Technol. 2018, 268, 292-299. [CrossRef]

8. Leung, X.Y.; Xue, L.; Wen, H. Framing the sharing economy: Toward a sustainable ecosystem. Tour. Manag. 2019, 71, 44-53. [CrossRef]

9. Yang, W.; Li, P.; Bo, D.; Chang, H. The optimization of formic acid hydrolysis of xylose in furfural production. Carbohydr. Res. 2012, 357, 53-61. [CrossRef]

10. Qi, L.; Mui, Y.F.; Lo, S.W.; Matthew, Y.; Geoffrey, R.A.; Istvan, T.H. Catalytic conversion of fructose, glucose, and sucrose to 5-(hydroxymethyl)furfural and levulinic and formic acids in $\gamma$-valerolactone as a green solvent. ACS Catal. 2014, 4, $1470-1477$. [CrossRef]

11. Morais, E.S.; Freire, M.G.; Freire, S.R.; Coutinho, A.P.; Silvestre, J.D. Enhanced conversion of xylan into furfural using acidic deep eutectic solvents with dual solvent and catalyst behavior. Chem. Sustain. Energy Mater. 2020, 13, 784-790. [CrossRef] [PubMed]

12. Bystrzanowska, M.; Tobiszewski, M. Assessment and design of greener deep eutectic solvents -A multicriteria decision analysis. J. Mol. Liq. 2021, 321, 114878. [CrossRef]

13. Chen, Z.; Reznicek, W.D.; Wang, C. Aqueous choline chloride: A novel solvent for switchgrass fractionation and subsequent hemicellulose conversion into furfural. ACS Sustain. Chem. Eng. 2018, 6, 6910-6919. [CrossRef]

14. He, Y.C.; Jiang, C.X.; Jiang, J.W.; Di, J.H.; Ding, Y.; Qing, Q.; Ma, C.L. One-pot chemo-enzymatic synthesis of furfuralcohol from xylose. Bioresour. Technol. 2017, 238, 698-705. [CrossRef] [PubMed]

15. Wang, L.J.; Zhao, X.; Zhang, S.T.; Lu, X.B. Pretreatment of corn stover with diluted acetic acid for enhancement of acidogenic fermentation. Bioresour. Technol. 2014, 158, 12-18. [CrossRef]

16. Chen, H.; Ruan, H.; Langrish, T.; Lu, X. Efficient catalytic transfer hydrogenation of furfural to furfuryl alcohol in near-critical isopropanol over $\mathrm{Cu} / \mathrm{MgO}-\mathrm{Al}_{2} \mathrm{O}_{3}$ catalyst. Mol. Catal. 2018, 445, 94-101. [CrossRef]

17. Aires, F.; Weerachawanasak, P.; Krawmanee, P.; Inkamhaeng, W.; Panpranot, J. Development of bimetallic Ni-Cu/SiO 2 catalysts for liquid phase selective hydrogenation of furfural to furfuryl alcohol. Catal. Commun. 2021, 149, 106221.

18. Li, J.; Zahid, M.; Sun, W.; Tian, X.; Zhu, Y. Synthesis of Pt supported on mesoporous g- $\mathrm{C}_{3} \mathrm{~N}_{4}$ modified by ammonium chloride and its efficiently selective hydrogenation of furfural to furfuryl alcohol. Appl. Surf. Sci. 2020, 528, 146983. [CrossRef]

19. Chen, J.; Sun, W.; Wang, Y.; Fang, W. Performant Au hydrogenation catalyst cooperated with $\mathrm{Cu}$-doped $\mathrm{Al}_{2} \mathrm{O}_{3}$ for selective conversion of furfural to furfuryl alcohol at ambient pressure. Green Energy Environ. 2020, 6, 546-556. [CrossRef]

20. Alejandra, R.M.; Rache, L.Y.; Brijaldo, M.H.; Romanelli, G.P.; Martinez, J.J. Biocatalytic transformation of furfural into furfuryl alcohol using resting cells of Bacillus cereus. Catal. Today 2021, 372, 220-225.

21. Bu, C.Y.; Yan, Y.X.; Zou, L.H.; Zheng, Z.J.; Ouyang, J. One-pot biosynthesis of furfuryl alcohol and lactic acid via a glucose coupled biphasic system using single Bacillus coagulans NL01. Bioresour. Technol. 2020, 313, 123705. [CrossRef]

22. Bu, C.Y.; Yan, Y.X.; Zou, L.H.; Ouyang, S.P.; Zheng, J.Z.; Ouyang, J. Comprehensive utilization of corncob for furfuryl alcohol production by chemo-enzymatic sequential catalysis in a biphasic system. Bioresour. Technol. 2021, 319, 124156. [CrossRef]

23. Li, Q.; Ren, J.Q.; Li, Q.; Di, J.H.; Ma, C.L.; He, Y.C. Sustainable conversion of biomass-derived $D$-xylose to furfuryl alcohol in a deep eutectic solvent-water system. ACS Sustain. Chem. Eng. 2021, 9, 10299-10308. [CrossRef]

24. Ji, L.; Tang, Z.Y.; Yang, D.; Ma, C.L.; He, Y.C. Improved one-pot synthesis of furfural from corn stalk with heterogeneous catalysis using corn stalk as biobased carrier in deep eutectic solvent-water system. Bioresour. Technol. 2021, 340, 125691. [CrossRef]

25. Loow, Y.L.; New, E.K.; Yang, G.H.; Ang, L.Y.; Foo, L.Y.W.; Wu, T.Y. Potential use of deep eutectic solvents to facilitate lignocellulosic biomass utilization and conversion. Cellulose 2017, 24, 3591-3618. [CrossRef]

26. Lopes, M.; Dussan, K.; Leahy, J.J. Enhancing the conversion of $D$-xylose into furfural at low temperatures using chloride salts as co-catalysts: Catalytic combination of $\mathrm{AlCl}_{3}$ and formic acid. Chem. Eng. J. 2017, 323, 278-286. [CrossRef]

27. Li, Y.Y.; Li, Q.; Zhang, P.Q.; Ma, C.L.; Xu, J.H.; He, Y.C. Catalytic conversion of corncob to furfuryl alcohol in tandem reaction with tin-loaded sulfonated zeote and NADPH-dependent reductase biocatalyst. Bioresour. Technol. 2021, 320, 124267. [CrossRef] [PubMed]

28. Ema, T.; Ide, S.; Okita, N.; Sakai, T. Highly efficient chemoenzymatic synthesis of methyl (R)-o-chloromandelate, a key intermediate for clopidogrel, via asymmetric reduction with recombinant Escherichia coli. Adv. Synth. Catal. 2008, 350, 2039-2044. [CrossRef]

29. Ema, T.; Yagasaki, H.; Okita, N.; Takeda, M.; Sakai, T. Asymmetric reduction of ketones using recombinant E. coli cells that produce a versatile carbonyl reductase with high enantioselectivity and broad substrate specificity. Tetrahedron 2006, 62, 6143-6149. [CrossRef]

30. Zhang, S.; Ma, C.; Li, Q.; Li, Q.; He, Y.C. Efficient chemoenzymatic valorization of biobased D-fructose into 2,5-bis(hydroxymethyl)furan with deep eutectic solvent Lactic acid:Betaine and Pseudomonas putida S12 whole cells. Bioresour. Technol. 2022, 344, 126299. [CrossRef]

31. Jia, H.Y.; Zong, M.H.; Zheng, G.W.; Li, N. One-pot enzyme cascade for controlled synthesis of furancarboxylic acids from 5-hydroxymethylfurfural by H2O2 internal recycling. ChemSusChem 2019, 12, 4764-4768. [CrossRef] [PubMed]

32. He, Y.C.; Jiang, C.X.; Chong, G.G.; Di, J.H.; Ma, C.L. Biological synthesis of 2,5-bis(hydroxymethyl)furan from biomass-derived 5-hydroxymethylfurfural by E. coli CCZU-K14 whole cells. Bioresour. Technol. 2018, 247, 1215-1220. [CrossRef] [PubMed]

33. He, Y.C.; Ding, Y.; Ma, C.L.; Di, J.H.; Jiang, C.X.; Li, A.T. One-pot conversion of biomass-derived xylose to furfuralcohol by a chemo-enzymatic sequential acid-catalyzed dehydration and bioreduction. Green Chem. 2017, 19, 3844-3850. [CrossRef] 
34. Lee, C.B.T.L.; Wu, T.Y. A review on solvent systems for furfural production from lignocellulosic biomass. Renew. Sustain. Energy Rev. 2021, 137, 110172. [CrossRef]

35. Xu, P.; Zheng, G.W.; Zong, M.H.; Li, N.; Lou, W.Y. Recent progress on deep eutectic solvents in biocatalysis. Bioresour Bioprocess. 2017, 4, 34. [CrossRef] [PubMed]

36. Dai, Y.; Row, K.H. Application of natural deep eutectic solvents in the extraction of quercetin from vegetables. Molecules 2019, 24, 2300. [CrossRef]

37. Panic, M.; Andlar, M.; Tisma, M.; Rezic, T.; Sibalic, D.; Bubalo, M.C.; Redovnikovic, I.R. Natural deep eutectic solvent as a unique solvent for valorisation of orange peel waste by the integrated biorefinery approach. Waste Manag. 2021, 120, 340-350. [CrossRef]

38. Kalhor, P.; Ghandi, K. Deep eutectic solvents for pretreatment, extraction, and catalysis of biomass and food waste. Molecules 2019, 24, 4012. [CrossRef]

39. Xu, G.C.; Li, H.; Xing, W.R.; Gong, L.; Dong, J.J.; Ni, Y. Facilely reducing recalcitrance of lignocellulosic biomass by a newly developed ethylamine based deep eutectic solvent for biobutanol fermentation. Biotechnol. Biofuels 2020, 13, 166. [CrossRef]

40. Kogje, A.; Ghosalkar, A. Xylitol production by Saccharomyces cerevisiae overexpressing different xylose reductases using non-detoxified hemicellulosic hydrolysate of corncob. 3 Biotech 2016, 6, 1-10. [CrossRef]

41. Yang, D.; Zhao, N.; Tang, S.; Zhu, X.; Ma, C.; Fan, B.; Liang, J.; Yu, B.; Yang, L.; He, Y.-C. A hybrid strategy for efficient valorization of bulrush into furoic acid in water-ChCl-based deep eutectic solvent. Ind. Crop. Prod. 2022, 177, 114434. [CrossRef] 